\title{
First Report of Root-lesion Nematode, Pratylenchus on New Host, Deverra tortuosa, in Mersa Matruh Coast, Egypt- A Pilot Study
}

\author{
El-Nuby A. S. M. \\ Plant Protect. Dept, Desert Res. Center, Cairo, Egypt \\ Corresponding author email: ahmedelnuby.drc@gmail.com
}

\begin{abstract}
Nematode survey was carried out in 2019 on wild plants viz., Aeluropus lagopoides (Molleih), Ammophila arenaria (Gazzoof), Cakile maritime (Figl el-gamal), Deverra tortuosa (guezah), Euphorbia paralias (Sakrran), Inula crithmeides (Golden samphire), Lotus polyphyllus (Qam el- gamal or Qrana), Ononis vaginalis (Hotaiba), Pancratium maritimum (Bosseil), Polygonum equisetiforme (Horsetail knotweed), Thymelaea hirsute (Mithnaan), and Zygophyllum album (Ratrayt), colonized the coastal sand dunes habitat of Mersa Matruh, Egypt. Specimens of root-lesion nematodes (Pratylenchus spp.) were collected from rhizosphere soil of D. tortuosa Synonym: Pituranthos tortuosus (Desf.) Benth. \& Hook f. Asch. \& Schweinf herb (family: Apiaceae, old family: Umbelliferae). Root-lesion nematode was identified based on morphological characteristics of females. According to available literature, this is the first report of Pratylenchus on wild plant (D. tortuosa) growing in Egypt. More surveys are needed to identify other genera or species of phytonematodes that might occur in Egypt, including weeds, grasses and wild plants in desert areas, also the dissemination of lesion nematode must be explored as well as other plant-parasitic nematodes and it is advisable to investigate the nearby cultivated plants.
\end{abstract}

Key words: First report, root-lesion nematode, Pratylenchus spp., wild plants, Deverra tortuosa, Egypt.

\section{INTRODUCTION}

In Egypt, phytoparasitic nematodes have been recorded when Preyer (1901) reported, in Alexandria, a nematode disorder of banana. Pathogenic nematodes viz., Tylenchulus, Pratylenchus and Meloidogyne were the main genera received major attention in earlier investigations concerning their occurrence on different hosts (Fikry, 1939; Oteifa, 1955; Oteifa, 1962; Oteifa, 1964; Tarjan, 1964 Oteifa and Tarjan, 1965). Previous surveys in Egypt reported about fifty four genera and one hundred and sixty species of phytonematodes were accompanied with many cultivated plants, grasses and weeds (Ibrahim et al., 2000). Knowledge respecting the incidence and host plants of plant- parasitic nematodes in Egypt is very necessary, since nematode pathogens, such as root-knot nematode (Meloidogyne), root-lesion (Pratylenchus) and other phytophagous nematodes (Abou-Elnaga, 1979; Abou- 
Elnaga, 1989; Ibrahim, 1990; Ibrahim and El-Sharkawy, 2001; Oteifa, 1962; Oteifa, 1964; Oteifa and Tarjan,1965 and Oteifa et al., 1997) are considered of economic importance on many crops.

The first species of the genus, Tylenchus pratensis De Man, 1880, was described by De Man (1880), then was designated by Filipjev (1934), as the type of its new genus, Pratylenchus. This genus Pratylenchus gained the true generic diagnosis by Filipjev (1936), as a group of nematodes possessing a Tylenchoid pharynx overlapping the anterior portion of the intestine and auniovarial gonad in adult females. The root-lesion nematodes occupy the third position after root-knot and cyst nematodes, because they have an economic impact on many crops, their wide host range and their distribution in almost each of cool, temperate and tropical ecosystems. (Castillo and Vovlas, 2007). Pratylenchus species are soil-borne pathogens, obligate biotrophic and are found in all most cultivated areas, also they are found in natural (with grasses) environments. Data from some northern temperate grasses and ecosystems confirmed that species of Pratylenchus (84\% incidence) were actually more frequently encountered than those of cyst $(21 \%)$ or root-knot $(19 \%)$ nematodes (De Goede \& Bongers, 1998). Although Pratylenchus species are polyphagous, as they are recognized worldwide as one of the major constraints of crops of primary economic importance, there are clear differences in host preferences amongst its species. The genus, Pratylenchus includes about 68 valid species of worldwide distribution that parasitize a wide variety of plants (more primitive or less specialized).They are mainly considered migratory endoparasites, causing severe root damage of crops, while their feeding primarily is in the cortical parenchyma. In other words, although they may also be found feeding ectoparasitically in the cortical parenchyma layer, damage to host plants is more directly related to their endoparasitic activity. In any case, Pratylenchus spp. were assumed to have a hit and-run parasitic behavior, remaining migratory throughout their life cycle. (Castillo and Vovlas, 2007).

The major part of the Egyptian Mediterranean coastal region is bordered by sand dunes of different natures and types. The belt of sand dunes (that composed mainly of white snow with oolitic calcareous granules) develops in south of the shore. The dunes have an uneven surface; creating many microhabitats that support different types of plant growth (Batanouny 1999). Because of few surveys were accomplished in Egyptian desert areas, the aim of this work was to check out the occurrence and biodiversity of phytonematode fauna associated with wild plants colonized Mediterranean coastal sand dunes of Mersa Matruh. On this basis, further steps should be carried out focusing on role of nematode pathogens as a threat to survival and biodiversity of wild plants in Mediterranean coastal sand dunes region as well as nearby cultivated plants.

\section{MATERIALS AND METHODS}

Sampling: Nematological survey was carried out in costal sand dunes area in north western coast of Egypt (Mediterranean coastal region of Mersa Matruh governorate) during autumn of 2019. A total of 132 soil and root samples (also entire plants for identification) were collected from the rhizosphere regions of the various wild plants. Single samples of each plant genus were pooled in about one $\mathrm{kg}$ soil to form a composite sample. The plant specimens were identified and authenticated (by the Plant Taxonomy Unit, Plant Ecology and Ranges Department, Desert Research Center (DRC). A voucher herbarium specimen was deposited in the herbarium of DRC. 
Plants were identified to species levels according to Boulos \& El-Hadidi (1994) and Boulos (2002).

Extraction and identification of nematodes: Soil samples were thoroughly mixed and $1 / 2$ pint $\approx 250 \mathrm{~cm}^{3}(\mathrm{ml})$ aliquots were taken for nematode extraction using Cobb's sieving and decanting technique followed by a modified Baermann technique (Hooper et al., 2005).Each soil sample was suspended in 2 liters of water, and after settling of coarse soil particles, the supernatant was poured through three sieves of different openings or apertures size $\approx 149,74$, and $45 \mu$ respectively and this step was repeated three times. The debris including the nematodes retained on the last two sieves was collected in 250-ml beakers. The solution was transferred to Baermann tray to be clearer. Phytonematodes were fixed in $2 \%$ hot formaldehyde solution, identified to generic level, counted and examined under a compound microscope (Hooper, 1970). Nematode identifications were based on the morphological characteristics of adult and larval forms (Mai \& Lyon, 1975; Handoo \& Golden, 1989 and Siddiqi, 2000).

\section{RESULTS AND DISCUSSION}

Among the twelve wild plants viz., Aeluropus lagopoides, Ammophila arenaria, Cakile maritime, Deverra tortuosa, Euphorbia paralias, Inula crithmeides, Lotus polyphyllos, Ononis vaginalis, Pancrtium maritimum, Polygonum equisetiforme, Thymelaea hirsuta and Zygophyllum album, collected during this study, only D. tortuosa (Fig.1 A), the sample position $31^{\circ} 29^{\prime} 12.7^{\prime \prime}-$ latitude - \& $26^{\circ}$ $36^{\prime} 25.1^{\prime \prime}$ - longitude -, was found to be associated with one of the most serious genera of phytoparasitic nematodes named Pratylenchus spp. (Fig.1 B). Other plant rhizosphere soils included only various forms of free living nematodes (non-stylet bearing forms). Earlier survey carried out, in Nile Delta of Egypt by Oteifa (1962), stated that Pratylenchus is not confined to particular plants or determined ecosystem and this species can acclimate to some hosts better than others, so decidedness of each species must be recognized to expect its hosts.

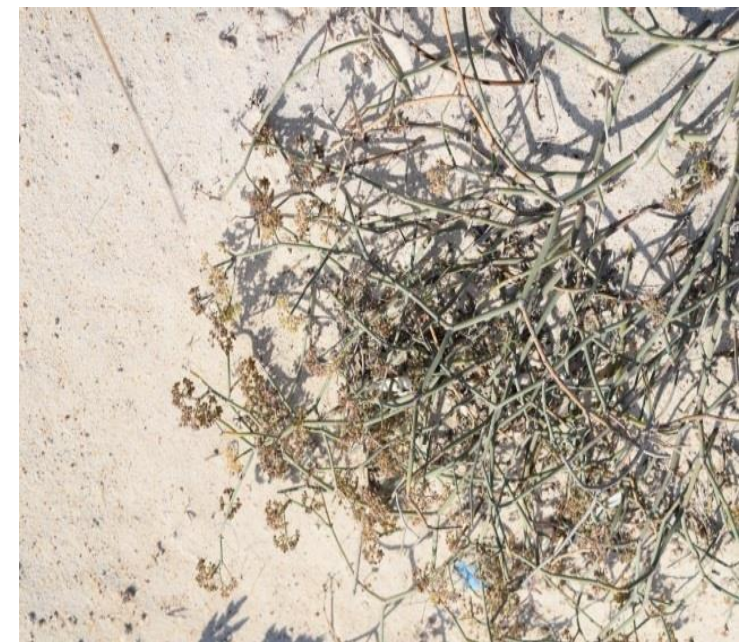

Fig. 1: (A) Deverra tortuosa in its habitat in Mediterranean coast of Mersa Matruh

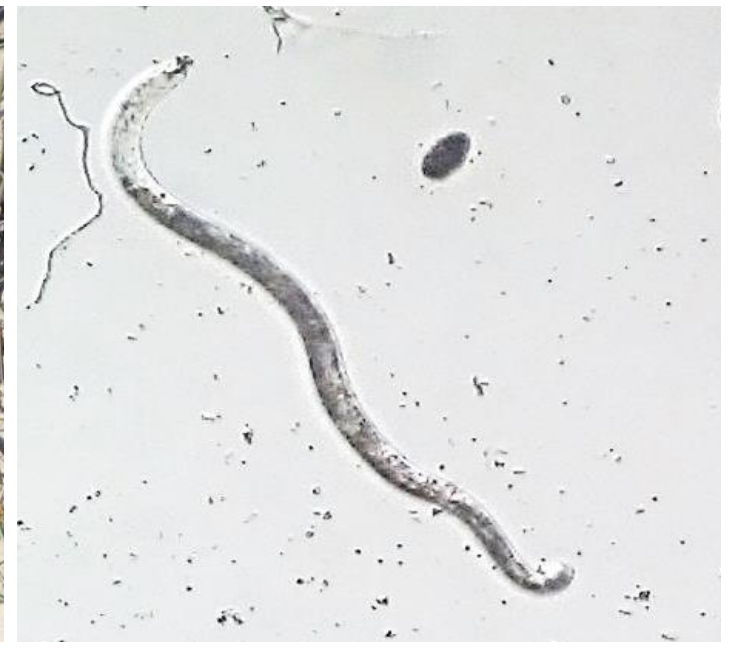

(B) Microscopic Photos of Pratylenchus recovered from rhizosphere soil of $D$. tortuosa

D. tortuosa and Polygonum equisetiforme were the most dominant plant species. Tymelaea hirsuta was the co-dominant species in western Mediterranean coastal region soil (Abd El-Ghani et al., 2014). Accordingly, root-lesion nematode may be 
derived from nearby olive trees by the rain (flood) and attached with $D$. tortuosa roots. Another investigation reported the ability of Pratylenchus to reproduce on Polygonum spp. (Belair et al., 2007), thus the transmission and parasitism of this nematode from Deverra to Polygonum are expected and may be vice versa. Pratylenchus spp. have wide host range that may include several hundred plant species. Although knowledge concerning to wild plant hosts species is rather scarce, it can be apparent that they can multiply also on wild plants belonging to the same plant family of the main host (Covarelli et al., 2011).

Occurrence of the nematode genus, Pratylenchus spp. associated with D. tortuosa was considered a new record in Egypt and D. tortuosa was considered to be a new host of root-lesion nematode.

Because of D. tortuosa is a widespread desert species, xerophytic and salinity tolerant plant and able to grow in different habitats (El-Lamey, 2015) and have high economic value in medicinal uses particularly (Serag et al., 2020), further studies on the same host $(D$. tortuosa) are needed to determine the effect of various inocula and reproductive potential of root- lesion nematode on its growth.

\section{Conclusion:}

Depending on our knowledge, this is the first record of occurrence of lesion nematode associated with $D$. tortuosa in Egypt. Results reported herein form a valuable database that open the way to further researches to study pathogenicity of root-lesion nematodes and its life cycle in D. tortuosa and to explore other wild plants as new hosts. Also, testing susceptibility of D. tortuosa to the infection with rootknot nematode, as it is the widest spread genus in Egypt. The study also fairs attention to determine the dissemination manners of root-lesion nematode or other plantparasitic nematodes in these desert coastal areas; finally, considering the occurrence of phytonematodes when found in near areas as well as restricting their transferring to healthy soils. Further works should be done to taxonomize and identify Pratylenchus to species level on D. tortuosa.

\section{REFERENCES}

Abd El-Ghani M.; Soliman, A. and Abd El-Fattah R. (2014). Spatial distribution and soil characteristics of the vegetation associated with common succulent plants in Egypt. Turk. J. Bot., 38: 550-565.

Abou-Elnaga, M. M. (1979). List of free-living and plant parasitic nematodes recognized from Egypt hitherto. Opuscula Zoologica (Budapest), 16: 3-10.

Abou-Elnaga, M. M. (1989). A survey of nematodes associated with some orchard crops with reference to certain new records of nematode species in Egypt. J Agric. Sci., Mansoura Univ., 1: 396-401.

Batanouny, K. (1999). The Mediterranean coastal dunes in Egypt: An Endangered landscape. Estuar. Coast. Shelf Sci., 49: 3-9.

Belair, G.; Dauphinais, N.; Benoit, D. L. and Fournier, Y. (2007). Reproduction of Pratylenchus penetrans on 24 Common Weeds in Potato Fields in Québec. J. Nematol. 39(4): 321-326. 
Boulos, L. (2002). Flora of Egypt: Volume Three (Verbinaceae-Compositae). AlHadara Publishing, Cairo, Egypt, pp. 373.

Boulos, L. and El-Hadidi, N. M. (1994). The Weed Flora of Egypt. American University in Cairo Press, Cairo, $361 \mathrm{pp}$.

Castillo, P. and Vovlas, N. (2007). Pratylenchus (Nematoda: Pratylenchidae): Diagnosis, Biology, Pathogenisity and Management. Nematology Monographs and Perspectives, vol. 6, Brill Academic Publishers, Leiden-Boston. 529 pp.

Covarelli, G.; Pannacci, E. and Greco, N. (2011). Nematode-wild plant interactions and their implication in nematode management. Redia, XCIV: 107-111.

De Goede, R. G. M. and Bongers, T. (1998). Nematode communities of northern temperate grassland ecosystems. Focus. Available in site https://research.wur.nl/en/publications/nematode-communities-of-northern temperate-grassland-ecosystems

De Man, J. G. (1880). Die einheimischen, frei in der reinen Erde und im süssen Wasser lebenden Nematoden. Vorläufiger Bericht und descriptivsystematischer Theil. Tijdschrift der Nederlandsche Dierkundige Vereeniging, 5: 1-104

El-Lamey, T. M. (2015). Contribution of solutes to the osmotic adjustment of Deverra tortuosa (Desf.) DC. J. Bio. \& Environ. Sci., 7(1): 380-395.

Fikry, A. (1939). Nematode disease of stone fruits. Egyptian Ministry of Agriculture Technical Service Bulletin 212.

Filipjev, I. N. (1934). The classification of the freeliving nematodes and their relation to the parasitic nematodes. Smithson. misc. Collns (Publication 3216), 89, 63 pp.

Filipjev, I. N. (1936). On the classification of the Tylenchinae. Proceedings of the Helminthological Society of Washington, 3: 80-82.

Handoo, Z. A. and Golden, A. M. (1989).A key and diagnostic compendium to the species of the genus Pratylenchus Filipjev, 1936 (lesion nematodes). J. Nematol. 21: 202-218

Hooper, D. J. (1970). Handling, fixing, staining and mounting nematodes. In: Southey, J. F. (Ed.). Laboratory methods for work with plant and soil nematodes. $5^{\text {th }}$ Edition. Her Majesty's Stationery Office, London, pp. 59-80.

Hooper, D. J.; Hallmann, J. and Subbotin, S. (2005). Methods for extracting and processing detection of plant and soil nematodes. In: Plant Parasitic Nematodes in Subtropical and Tropical Agriculture, $2^{\text {nd }}$ Edition, pp. 53-86 (Luc, M., Sikora, R.A., Bridge, J. (Eds). Wallingford, UK: CABI Publishing.

Ibrahim, I. K .A. and El-Sharkawy, T. A. (2001). Genera and species of phytoparasitic nematodes and the associated host plants in Egypt. Adv. Agric. Res. Egypt, 3: $75-95$.

Ibrahim, I. K. A. (1990). The status of phytoparasitic nematodes and the associated plants in Egypt. Inter. Nematol. Netw. Newslett., 7: 33-38.

Ibrahim, I. K. A.; Handoo, Z. A. and El-Sherbiny, A. A. (2000). A Survey of phytoparasitic nematodes on cultivated and non-cultivated plants in Northwestern Egypt. Supplement to the J. Nematol. 32(4S): 478-485.

Mai, W. F. and Lyon, H. H. (1975). Pictorial key to genera of plant-parasitic nematodes. Ithaca, NY: Cornell University Press, USA. No. $4^{\text {th }}$ revised, pp.221.

Oteifa, B. A. (1955). Occurrence of citrus nematode in Egypt. Plant Dis. Rep. 33: 989.

Oteifa, B. A. (1962). Species of root-lesion nematodes commonly associated with economic crops in the Delta of U.A.R. Plant Dis. Rep. 46:572-575. 
Oteifa, B. A. (1964). A taxonomic guide to the common genera of soil and plant nematodes with a supplement on current known economic parasitic species of U.A.R. Giza, U.A.R.: Nematology Unit, National Research Centre.

Oteifa, B. A. and Tarjan, A. C. (1965). Potentially important plant parasitic nematodes present in established orchards of newly-reclaimed sandy areas of the U.A.R. Plant Dis. Rep. 49: 596-597.

Oteifa, B. A.; Shams El-Dean, M. M. and El Hamawi, M. H. (1997). A preliminary compiled study on the biodiversity of free-living, plant and insect parasitic nematodes in Egypt. Egypt. J. Agronematol. 1:1-36.

Preyer, A. (1901). On a new banana disease in Egypt. J. Khediv. Agr. Soc., 3: 242.

Serag, M. S.; Khedr, A. A. and Amer, N. G. (2020). Ecological and essential oils characteristics of Deverra tortuosa (Desf.) DC. in Egyptian deserts African J. Biol. Sci. 16 (1): 11-20.

Siddiqi, M. R. (2000). Tylenchida Parasites of Plants and Insects. Second Ed. CAB International, Wallingford, UK, $848 \mathrm{pp}$.

Tarjan, A. C. (1964). Plant parasitic nematodes in the United Arab Republic. FAO Plant Prot. Bull. 12: 49-56.

\section{الملخص العربي}

\section{تقرير أول عن تواجد نيماتود التقرح (Pratylenchus) علي عائل جديا ( Deverra) (tortuosa}

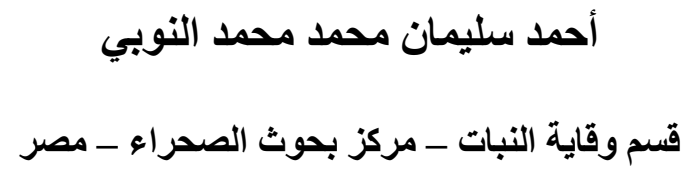

اجريت دراسة الحصر هذه فى بيئة الكثبان الرملية لساحل البحر المتوسط بمرسي مطروح بهدف

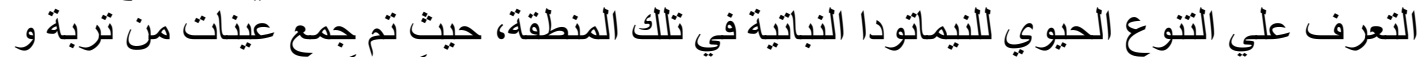

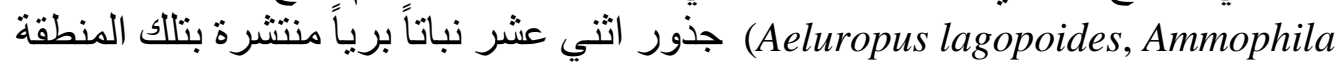
arenaria Cakile maritime, Deverra tortuosa, Euphorbia paralias, Inula crithmeides, Lotus polyphyllus, Ononis vaginalis, Pancratium maritim, Polygonum equisetiforme, Thymelaea hirsute and Zygophyllum album)

أظهرت النتائج وجود نيماتودا حرة المعيشة متنوعة في كل العينات، أما بالنسبة للنيماتودا المتطفلة علي النبات فقد تم تسجيل جنس واحد هو

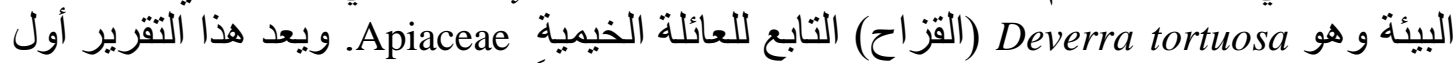
تسجيل لنيماتودا تقرح الجذور Pratylenchus المنطفلة نباتياً علي عائل جديد (بري) وفي بيئة

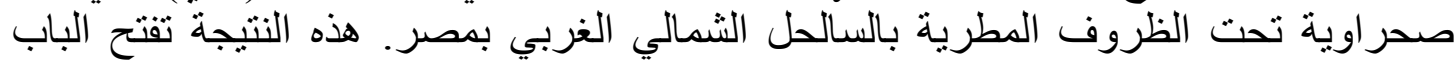

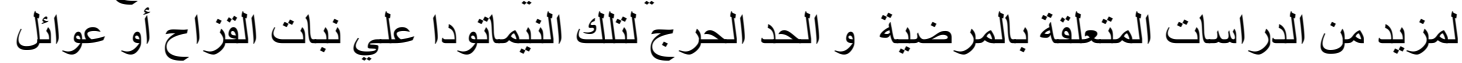

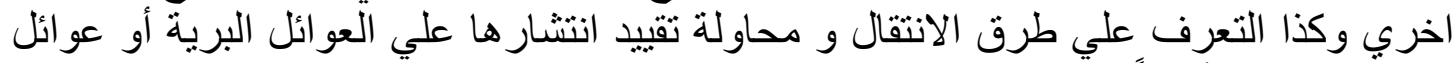

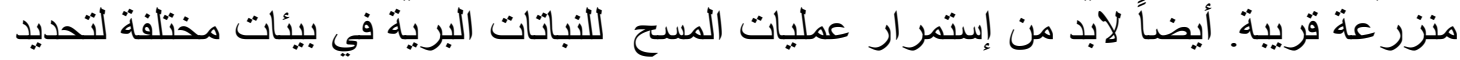
المدي العوائلي لتلك النيماتوداو التعرف علية علي حالة الفونا النيماتودية بتلك البيئات الصحرو اية. 